\title{
Factors associated with diabetic foot amputations
}

\author{
Fatores associados a amputações por pé diabético \\ Isabel Cristina Ramos Vieira Santos', Eduardo Freese de Carvalho², Wayner Vieira de Souza², \\ Emídio Cavalcanti de Albuquerque ${ }^{3}$
}

\begin{abstract}
Background: Diabetes and the problem of the diabetic foot specifically are a severe burden on the public healthcare system. Amputations caused by this condition are still common in our setting (Brazil), although the true magnitude of the problem is not known with certainty. Lower limb amputation rates have come to be seen as an indicator of the quality of preventative care of the diabetic foot. Objective: To identify associations between amputations and factors related to people, to morbidities and to primary care received. Methods: This was a cross-sectional study of a sample of 137 patients with diabetic feet admitted to a large hospital in the city of Recife, Pernambuco, Brazil. Logistic regression analysis was conducted. Results: Associations with amputation were detected for the following variables: age over 60; resident of the Metro zone; income of three minimum salaries or less; presence of gangrene on admission; glycemia $\geq 126 \mathrm{mg} / \mathrm{dL}$; smoking; not receiving information about results of glycemia testing; not having feet examined, and not being given guidance on caring for feet at consultations during the previous year. Conclusions: Factors related to Primary Care, such as time since onset of ulcers, information about results of glycemia testing and lack of guidance on how to care for their feet, were associated with occurrence of lower limb amputations.
\end{abstract}

Keywords: diabetic foot; amputation; primary care.

\begin{abstract}
Resumo
Contexto: $O$ diabetes e especificamente o problema do pé diabético representam grave adversidade ao sistema de saúde pública. As amputações resultantes deste agravo ainda são frequentes em nosso meio, embora não se conheça ao certo a sua magnitude. A taxa de amputações de membros inferiores tem sido considerada um indicador da qualidade dos cuidados preventivos do pé diabético. Objetivo: Identificar a existência de associação entre amputações e fatores relacionados às pessoas, à morbidade e à atenção básica recebida. Métodos: Estudo transversal que incluiu uma amostra de 137 portadores de pé diabético internados em hospital de grande porte da cidade do Recife. Realizou-se análise de regressão logística. Resultados: Verificou-se associação para as variáveis: idade de 60 anos ou mais; procedência da Região metropolitana; renda de até três salários mínimos; presença de gangrena à admissão; glicemia de 126 mg/ dL ou mais; tabagismo; não receber informação dos resultados da glicemia; não ter os pés examinados, e não receber orientação sobre cuidados com os pés nas consultas do ano anterior. Conclusões: Fatores relacionados à Atenção Básica, tais como o tempo de ocorrência da úlcera, a informação dos resultados do exame de glicemia e a falta de orientação sobre cuidados com os pés, estiveram associados com a ocorrência de amputações de membros inferiores.
\end{abstract}

Palavras-chave: pé diabético; amputação; atenção básica.

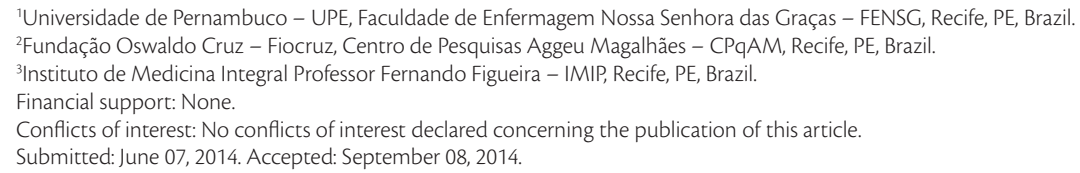




\section{INTRODUCTION}

Ulcers of the diabetic foot and resulting lower limb amputations are common, complex and incapacitating complications of diabetes. Prevalence rates are increasing all the world and the incidence of diabetic foot ulcers is increasing at a higher rate than other complications of diabetes. ${ }^{1,2}$

In the United States, diabetic patients account for around $3 \%$ of the total population and more than $50 \%$ of them suffer lower limb amputations. Around 1 to $4 \%$ of diabetic patients develop foot ulcers each year and around $15 \%$ will suffer ulceration at least once in their lives. ${ }^{2,3}$

Additionally, it is estimated that from 30 to $50 \%$ of those who have an amputation will require additional amputations within 1 to 3 years and $50 \%$ of them will die within 5 years of the first major amputation. ${ }^{1}$

Diabetes, and specifically the problem of the diabetic foot, represent a severe challenge to and burden on the public health system. Several European countries and also organizations such as the World Health Organization and the International Diabetes Federation have set a target for reduction of amputation rates by $50 \%{ }^{4}$

This target can be hit by means of adoption of simple measures for preventative care, diagnosis and more effective treatment during the early stages of the disease. ${ }^{4-7}$

Although controversial, lower limb amputation rates have come to be viewed as an indicator of the quality of care of the diabetic foot. Therefore, it is essential to understand the factors associated with utilization of hospital services, in order to monitor preventative care, which in turn is primarily in order to address potentially avoidable morbidity at this level of care. ${ }^{8}$

The objective of this study was to identify associations between amputations and factors related to people, to morbidities and to primary care.

\section{METHODS}

This was a cross-sectional epidemiological study conducted to identify factors associated with the outcome diabetic foot amputations, analyzing factors related to people, to morbidity and to (preventative) Primary Care received, this last because the condition can be avoided, depending on the preventative action that is taken.

The setting chosen for the study was one of the largest hospitals on the public health system in the Brazilian state of Pernambuco. The hospital was chosen because it is one of only three in the state that has a specialist vascular clinic that treats patients with diabetic feet.

The study population comprised all diabetic foot patients admitted for treatment and totaled 151 patients. After application of the inclusion criterion (patients with a diagnosis on their medical records of ischemic, neuropathic or infectious diabetic foot, with class 2 to 5 ulceration according to the Wagner classification) and exclusion criteria (never having attended primary care or a lack of the physical and/or mental conditions necessary to answer the questions), data were analyzed on a total of 137 patients, which equates to $90.7 \%$ of the population that had been admitted with the condition of interest.

A questionnaire was constructed based on the International Consensus on the Diabetic Foot ${ }^{9}$ and the Arterial Hypertension and Diabetes Manual, ${ }^{10}$ which is the Brazilian Ministry of Health's normative standard, published to guide reorganization of primary care for these two diseases.

The first step in data collection was a daily review of admissions to identify diabetic foot patients at the vascular clinic, using the clinic's records and individual patient records to select those that fit the study criteria. The second stage in data collection was administration of the questionnaire in interview format, after patients had provided consent.

The definition of amputations used for this study include both major amputations, i.e. those above the level of the ankle, and minor amputations (disarticulation of the ankle or below). ${ }^{9}$

In addition to the dependent variable 'amputation', the independent variables analyzed were related either to people (age, sex, origin, educational level and income); to morbidity (time since diagnosis of DM [TDM], point at which informed of DM diagnosis [before or after admission], circumstances of DM diagnosis [before or after onset of foot condition], time since onset of current problem, time on treatment, presence of gangrene on admission, glycemia on admission, smoking and prior amputation); or to (preventative) Primary Care received (number of consultations, glycemia testing, information about glycemia test results, foot examinations, guidance on caring for feet, nutritional guidance, advice about physical activity, use of medication to control DM and availability of medication, all of which were with reference to the previous 12 months).

Statistical analysis involved construction of frequency distributions and the independence of explanatory variables and the outcome 'amputation' 
was analyzed using the chi-square test with Yates' correction.

In both bivariate and multivariate analyses, odds ratios (OR) were used to estimate relative risk, with a $95 \%$ confidence interval $(95 \% \mathrm{CI})$. Logistic regression modeling was employed to construct estimations of the probability of the dependent variable (amputation) as a function of the explanatory variables.

All variables that were associated with amputations to a level of $p \leq 0.20$ in the bivariate analysis were included in the initial logistic model, except for variables with very low frequencies and high odds, indicating that they were confounding factors. Variables were then excluded one-by-one using the Backward Stepwise method (Likelihood Ratio). All analyses were conducted to a significance level of $5 \%$.

Data were double input to SPSS version 13.0, which was also used for the analyses.

The project was approved by the Research Ethics Committee under registration number CAAE: 1025.0.000.095-06.

\section{RESULTS}

Eight-five of the 137 patients studied underwent some type of amputation, while the remaining 52 were receiving conservative treatment (revascularization or clinical procedures).

\section{Amputations and factors related to people}

Within the subset of patients who underwent amputations $(\mathrm{n}=85)$, it can be observed in Table 1 that the age group 60 or over was the most frequent $(61.2 \%)$.

Tests for the association between amputation and the variable 'sex' showed that male patients had more amputations when compared to female patients; but the difference was not significant $(\mathrm{p}=0.751)$. There were also more amputations among residents of the Metro zone (58.8\%).

Educational level and income were associated with greater frequency of amputations for the categories 0-4 years' schooling (52.9\%) and up to three times the minimum wage $(83.5 \%)$ respectively. The differences observed for age, origin and income were statistically significant to $5 \%$.

\section{Amputations and factors related to morbidity}

Patients who did have amputations reported a time since diagnosis of diabetes mellitus (TDM) greater than 5 years, the majority $(71.4 \%)$ of them stated that they only found out about their condition after an admission and $54.1 \%$ of them only found out they were diabetic after developing foot ulcers (Table 2).

The patients studied reported having their current foot problems for more than 1 month $(83.5 \%)$ and having waited more than 1 month for care $(81.2 \%)$. According to the bivariate analysis, these patients had probabilities of suffering an amputation that were 3 times (95\% CI: $1.33-7.64)$ and 2.7 times $(95 \% \mathrm{CI}$ : 1.15-6.33) greater than the remainder of the sample.

Among the subset of patients who had amputations, gangrene was present on admission in $85.9 \%$ and those that had this complication on admission had a 3 times greater chance of amputation.

Table 1. Amputations and variables related to people.

\begin{tabular}{|c|c|c|c|c|c|c|c|}
\hline \multirow{2}{*}{ Variables } & \multicolumn{4}{|c|}{ Amputations } & \multirow{2}{*}{ OR } & \multirow{2}{*}{$95 \% \mathrm{Cl}$} & \multirow{2}{*}{$p^{\prime}$} \\
\hline & Yes & $\%$ & No & $\%$ & & & \\
\hline \multicolumn{8}{|l|}{ Age } \\
\hline 60 or over & 52 & 61.2 & 41 & 78.8 & 0.42 & $0.18-1.00$ & 0.049 \\
\hline Less than 60 years & 33 & 38.8 & 11 & 21.2 & 1 & & \\
\hline \multicolumn{8}{|l|}{ Sex } \\
\hline Male & 47 & 55.3 & 31 & 59.6 & 0.84 & $0.39-1.79$ & 0.751 \\
\hline Female & 38 & 44.7 & 21 & 40.4 & 1 & & \\
\hline \multicolumn{8}{|l|}{ Origin } \\
\hline Metro zone & 50 & 58.8 & 40 & 76.9 & 0.43 & $0.18-0.99$ & 0.048 \\
\hline Interior & 35 & 41.2 & 12 & 23.1 & 1 & & \\
\hline \multicolumn{8}{|l|}{ Educational level } \\
\hline $0-4$ years & 45 & 52.9 & 37 & 71.2 & 0.46 & $0.20-1.01$ & 0.054 \\
\hline 4 years or more & 40 & 47.1 & 15 & 28.8 & 1 & & \\
\hline \multicolumn{8}{|l|}{ Income** } \\
\hline Up to $3 \mathrm{MW}$ & 71 & 83.5 & 50 & 96.2 & 0.20 & $0.03-1.00$ & 0.050 \\
\hline $3 \mathrm{MW}$ or more & 14 & 16.5 & 2 & 3.8 & 1 & & \\
\hline
\end{tabular}

\footnotetext{
${ }^{*}$ Chi-square test with Yates' correction. ${ }^{* *} \mathrm{MW}=$ minimum wage.
} 
Table 2. Amputations and variables related to morbidity.

\begin{tabular}{|c|c|c|c|c|c|c|c|}
\hline \multirow{2}{*}{ Variables } & \multicolumn{4}{|c|}{ Amputations } & \multirow{2}{*}{ OR } & \multirow{2}{*}{$95 \% \mathrm{Cl}$} & \multirow{2}{*}{$\mathrm{p}^{*}$} \\
\hline & Yes & $\%$ & No & $\%$ & & & \\
\hline \multicolumn{8}{|l|}{ TDM } \\
\hline More than 5 years & 42 & 50.6 & 29 & 55.8 & 0.81 & $0.38-1.73$ & 0.683 \\
\hline Up to5 years & 41 & 49.4 & 23 & 44.2 & 1 & & \\
\hline \multicolumn{8}{|l|}{ Informed of DM Diagnosis } \\
\hline After admission & 60 & 71.4 & 22 & 44.0 & 3.18 & $1.53-6.61$ & 0.003 \\
\hline Before admission & 24 & 28.6 & 28 & 56.0 & 1 & & \\
\hline \multicolumn{8}{|l|}{ Circumstance of Diagnosis } \\
\hline After onset of foot problem & 46 & 54.1 & 41 & 78.8 & 0.32 & $0.13-0.74$ & 0.006 \\
\hline Before onset of foot problem & 39 & 45.9 & 11 & 21.2 & 1 & & \\
\hline \multicolumn{8}{|c|}{ Time since onset of current problem } \\
\hline More than 1 month & 71 & 83.5 & 32 & 61.5 & 3.17 & $1.33-7.64$ & 0.007 \\
\hline Up to 1 month & 14 & 16.5 & 20 & 38.5 & 1 & & \\
\hline \multicolumn{8}{|l|}{ Time waiting for care } \\
\hline More than 1 month & 69 & 81.2 & 32 & 61.5 & 2.70 & $1.15-6.33$ & 0.019 \\
\hline Up to 1 month & 16 & 18.8 & 20 & 38.5 & 1 & & \\
\hline \multicolumn{8}{|l|}{ Gangrene on admission } \\
\hline Yes & 73 & 85.9 & 34 & 65.4 & 3.22 & $1.39-7.43$ & 0.009 \\
\hline No & 12 & 14.1 & 18 & 34.6 & 1 & & \\
\hline \multicolumn{8}{|l|}{ Glycemia on admission } \\
\hline$\geq 126 \mathrm{mg} / \mathrm{dL}$ & 56 & 65.9 & 47 & 45.6 & 0.21 & $0.06-0.62$ & 0.003 \\
\hline$<126 \mathrm{mg} / \mathrm{dL}$ & 29 & 34.1 & 5 & 9.6 & 1 & & \\
\hline \multicolumn{8}{|l|}{ Smoking } \\
\hline Yes & 70 & 82.4 & 22 & 42.3 & 6.36 & $2.90-13.93$ & 0.000 \\
\hline No & 15 & 17.6 & 30 & 57.7 & 1 & & \\
\hline \multicolumn{8}{|l|}{ Previous amputation } \\
\hline Yes & 78 & 91.8 & 38 & 73.1 & 4.11 & $1.53-11.01$ & 0.007 \\
\hline No & 7 & 8.2 & 14 & 26.9 & 1 & & \\
\hline
\end{tabular}

* Chi-square test with Yates' correction.

Glycemia results on admission showed that $65.9 \%$ of the patients who suffered amputation arrived at hospital with levels over the cutoff point. Mean concentration was $212 \mathrm{mg} / \mathrm{dL}$ and the median was $183 \mathrm{mg} / \mathrm{dL} \pm 86.7$. This variable had a statistically significant association with amputation $(\mathrm{p}=0.003)$.

Among the subset of patients who had amputations, $82.4 \%$ reported smoking and the difference in occurrence of amputation between those who smoked and those who did not was significant to $1 \%$, with a 6.4 times greater probability $(95 \% \mathrm{CI}: 2.90-13.93)$ of amputation among smokers.

There was a high prevalence of previous history of amputation among those subjected to amputation during the current admission (92\%). Analysis of this variable revealed a statistically significant difference at the level of $5 \%$, confirming the association between prior amputation and current amputation. Analysis showed that those with a history of previous amputation exhibited a four times greater chance
(95\%CI: 1.53-11.01) of amputation during the current admission.

\section{Amputations and factors related to (preventative) Primary Care received}

A little over half of the patients who underwent amputations (52.9\%) reported having attended three or fewer consultations during the previous year and the difference between these patients and patients who attended higher numbers of consultations was statistically significant to $5 \%$, indicating an association with amputation, as can be observed from the results listed in Table 3.

With regard to testing of plasma glycemia, $72.8 \%$ of the patients who had amputations reported that glycemia had not been tested and $71.1 \%$ of same subset reported that they had not received information about glycemia test results. Both of these variables exhibited statistically significant differences with a three times greater chance of amputation $(95 \% \mathrm{CI}$ : 1.33-5.87 and 1.38-6.09, respectively) among 
Table 3. Amputations and variables related to (preventative) primary care received.

\begin{tabular}{|c|c|c|c|c|c|c|c|}
\hline \multirow{2}{*}{ Variables } & \multicolumn{4}{|c|}{ Amputations } & \multirow{2}{*}{ OR } & \multirow{2}{*}{$95 \% \mathrm{Cl}$} & \multirow{2}{*}{$p$-value* } \\
\hline & Yes & $\%$ & No & $\%$ & & & \\
\hline \multicolumn{8}{|l|}{ No. consultations } \\
\hline Up to 3 & 45 & 52.9 & 41 & 78.8 & 0.30 & $0.13-0.71$ & 0.004 \\
\hline More than 3 & 40 & 47.1 & 11 & 21.2 & 1 & & \\
\hline \multicolumn{8}{|l|}{ Glycemia test } \\
\hline No & 59 & 72.8 & 24 & 49.0 & 2.79 & $1.33-5.87$ & 0.011 \\
\hline Yes & 22 & 27.2 & 25 & 51.0 & 1 & & \\
\hline \multicolumn{8}{|c|}{ Information about results } \\
\hline No & 59 & 71.1 & 22 & 45.8 & 2.91 & $1.38-6.09$ & 0.007 \\
\hline Yes & 24 & 28.9 & 26 & 54.2 & 1 & & \\
\hline \multicolumn{8}{|l|}{ Foot examination } \\
\hline No & 69 & 81.2 & 28 & 56.0 & 3.39 & $1.45-7.97$ & 0.003 \\
\hline Yes & 16 & 18.8 & 22 & 44.0 & 1 & & \\
\hline \multicolumn{8}{|c|}{ Guidance on caring for feet } \\
\hline No & 63 & 74.1 & 20 & 39.2 & 4.44 & $1.98-10.02$ & 0.000 \\
\hline Yes & 22 & 25.9 & 31 & 60.8 & 1 & & \\
\hline \multicolumn{8}{|l|}{ Nutritional guidance } \\
\hline No & 19 & 23.8 & 12 & 25.0 & 0.93 & $0.38-2.33$ & 0.958 \\
\hline Yes & 61 & 76.3 & 36 & 75.0 & 1 & & \\
\hline \multicolumn{8}{|c|}{ Advice about physical activity } \\
\hline No & 39 & 48.8 & 20 & 41.7 & 1.33 & $0.61-2.92$ & 0.552 \\
\hline Yes & 41 & 51.3 & 28 & 58.3 & 1 & & \\
\hline \multicolumn{8}{|l|}{ Takes DM medication } \\
\hline No & 50 & 58.8 & 15 & 28.8 & 3.52 & $1.68-7.38$ & 0.001 \\
\hline Yes & 35 & 41.2 & 37 & 71.2 & 1 & & \\
\hline \multicolumn{8}{|l|}{ Medication available } \\
\hline No & 18 & 21.2 & 14 & 28.0 & 0.69 & $0.29-1.67$ & 0.490 \\
\hline Yes & 67 & 78.8 & 36 & 72.0 & & & \\
\hline
\end{tabular}

* Chi-square test with Yates' correction.

patients who did not have glycemia tests and did not receive information about the results.

Both examination of the feet and guidance about caring for the feet exhibited significant differences. Among the subset of patients who had amputations, $81.2 \%$ reported that their feet were not examined at consultations (OR: 3.39; 95\%CI: 1.45-7.97) and $74.1 \%$ reported that they had not been given instructions about how to care for their feet (OR: 4.44; 95\% CI: 1.98-10.02).

When the outcome amputation was analyzed with respect to nutritional guidance and advice on physical activity, it was found that there were no significant differences.

With regards to variables related to use of medication to control diabetes, $58.8 \%$ of the patients reported they did not take such medications ( $p=0.001$ ), although $78.8 \%$ of them reported that these medications were available at their health centers. The difference for this last variable between patients who had amputations and patients who did not was not statistically significant. However, not taking medication for DM was associated with occurrence of amputation, with a 3.5 times greater chance (95\%CI: 1.68-7.38).

The result of the logistic regression analysis of the variables related to people, to morbidity and to (preventative) primary care received is shown in Table 4.

As can be observed, time since onset of current problem greater than 1 month $(\mathrm{OR}=4.419 ; 95 \% \mathrm{CI}$ : $1.502-13.007)$ and failure to receive guidance on caring for feet $(\mathrm{OR}=3.583$; 95\%CI:1.243-10.328) are strongly associated with the occurrence of amputations. Not being informed about the results of the glycemia tests conducted $(\mathrm{OR}=3.341 ; 95 \% \mathrm{CI}$ : 1.254-8.899) and presence of gangrene on admission $(\mathrm{OR}=3.086$; 95\% $\mathrm{CI}: 0.920-10.352)$ were both also associated with the outcome. 
Table 4. Multivariate analysis of variables associated with occurrence of amputations.

\begin{tabular}{|c|c|c|c|}
\hline Variables & OR & IC [95\%] & $p$-value \\
\hline \multicolumn{4}{|l|}{ Origin } \\
\hline Interior & 1.000 & - & 0.072 \\
\hline Metro zone & 0.357 & $0.116-1.098$ & \\
\hline \multicolumn{4}{|l|}{ Gangrene on admission } \\
\hline No & 1.000 & - & 0.068 \\
\hline Yes & 3.086 & $0.920-10.352$ & \\
\hline \multicolumn{4}{|c|}{ Time since onset of current problem } \\
\hline Up to 1 month & 1.000 & - & 0.007 \\
\hline More than 1 month & 4.419 & $1.502-13.007$ & \\
\hline \multicolumn{4}{|l|}{ Glycemia on admission } \\
\hline$\leq 126 \mathrm{mg} / \mathrm{dL}$ & 1.000 & - & 0.113 \\
\hline$>126 \mathrm{mg} / \mathrm{dL}$ & 0.297 & $0.066-1.332$ & \\
\hline \multicolumn{4}{|l|}{ Circumstance of Diagnosis } \\
\hline Before onset of foot problem & 1.000 & - & 0.043 \\
\hline After onset of foot problem & 0.298 & $0.092-0.962$ & \\
\hline \multicolumn{4}{|l|}{ No. consultations } \\
\hline More than 3 & 1.000 & - & 0.045 \\
\hline Up to 3 & 0.299 & $0.092-0.974$ & \\
\hline \multicolumn{4}{|l|}{ Information about results } \\
\hline Yes & 1.000 & - & 0.016 \\
\hline No & 3.341 & $1.254-8.899$ & \\
\hline \multicolumn{4}{|l|}{ Guidance on caring for feet } \\
\hline Yes & 1.000 & - & 0.018 \\
\hline No & 3.583 & $1.243-10.328$ & \\
\hline
\end{tabular}

\section{DISCUSSION}

Age has been identified as a risk factor for amputations secondary to diabetic feet in several different studies. ${ }^{3,8,11,12}$ However, specifically in the present study, although age exhibited a statistically significant difference in bivariate analysis, significance was not maintained in the final regression model.

In contrast, region of origin was associated with occurrence of amputation in both analyses, with a higher frequency of people resident in the Metro zone among those patients who underwent amputations. This finding about the origins of patients with relation to the condition diabetic foot and amputation is a sign that greater reflection is needed with regard to the social conditions of the population at risk and also raises questions with relation to the diabetic foot situation in provincial areas in the interior of the state, which is a subject requiring further investigation.

The high proportion of patients who only discovered they had diabetes after developing problems with their feet is evidence that difficulties still remain with ensuring diagnosis and follow-up of diabetes mellitus. Since it is known that the diabetic foot is associated with long disease duration and poor metabolic control, ${ }^{4,12,13}$ these services, which should be provided by Primary Care services, have a direct relationship with the prevalence of amputations because of the diabetic foot.

Along the same lines, the time since onset of the current problem is indicative of the most recent occurrence, whether the first or a continuation of a process lasting many years, and is an expression both of a need for care and of difficulties accessing and utilizing the healthcare system.

The results observed revealed significant differences between patients who had had a foot problem for more than 1 month and those who had not. Multivariate analysis showed that the subset that had suffered from foot ulcers for more than 1 month had a 3 times greater probability of suffering an amputation than those whose problem had been detected more recently, thereby demonstrating that this is a risk factor for amputation. It is of note that no similar data could be found in the literature that were appropriate for comparison.

The variable gangrene at admission indicates the severity of the case at the point that the patient is seen at a healthcare institution of a higher level 
of complexity and those who presented at hospital already with gangrene had a three times greater chance of undergoing amputation than those who did not have the condition at admission.

In theory, this finding is evidence of either a lack of access to or a failure to comply with primary care and compounds other risk factors for amputation, such as time since becoming aware of the disease and time since onset of current problem. Bearing in mind that the diabetic foot is avoidable through early diagnosis and preventative measures, the high rates of gangrene by the time of hospital admission, the numbers of patients who only became aware they had DM after a problem with their feet had occurred and the proportion who had ulcers that had been progressing for more than 1 month all show the existence of problems with the effectiveness of primary care actions.

The high rates of hyperglycemia on admission observed in this study are compatible with the results of other studies. ${ }^{3,14}$ Although there was an association between the subset with glycemia levels $\geq 126 \mathrm{mg} / \mathrm{dL}$ and amputations, both the analysis using odds ratios and the logistic regression modeling indicated that the association between this variable and occurrence of amputations was weak, probably because of the small number of patients analyzed.

Several different studies have shown how poor glycemic control encourages emergence and development of chronic complications and increases the risk of neuropathy, which is one of the most important factors in triggering ulceration of the feet, but there are no studies demonstrating a direct relationship between hyperglycemia and amputations. ${ }^{11,13-15}$

There is consistent evidence to show that any improvement in control of glycemia reduces the risk of microvascular and neuropathic complications and their progression. ${ }^{6,9}$

With regard to information about the results of this test, ignorance of the normal value for glycemia was associated with a three times greater chance of loss of the limb at the most recent admission.

Poor metabolic control and failure to provide information about the result are both factors that compromise adequate management of the diabetic foot, exposing patients to unpleasant outcomes.

Recognition of co-responsibility and the need to develop autonomy and initiative-taking in diabetic patients, through establishment of relationships of solidarity between Primary Care professionals and their clients, has the potential to improve self-care through the probable effect of their satisfaction with the results of compliance with treatment. In contrast, patients who are not compliant with treatment have a 50 times greater probability of suffering from foot ulcers and a 20 times greater probability of amputation than those who correctly follow guidance. ${ }^{6,16,17}$

The finding of 3 or fewer consultations attended during the previous year, combined with time since onset of current problem, high glycemia levels and presence of gangrene on admission, reveals difficulties with screening and follow-up by primary care services and shows a failure to provide coverage and surveillance of this complication.

The primary care professionals' training manual recommends that, when faced with chronic complications in unstable patients with inadequate control, consultations should be scheduled every 2 or 3 months, which is the equivalent of four to six times a year. ${ }^{10}$ The International Consensus on the Diabetic Foot recommends that patients with a prior history of amputation should attend consultations at intervals of 1 to 3 months. ${ }^{9}$

Not conducting foot examinations during the previous year with the objective of prevention or control of the diabetic foot was associated with a 3.39 times greater probability of patients suffering an amputation, according to the bivariate analysis. In line with this finding, a lack of guidance about how to care for the feet was associated with approximately 3.6 times greater chance of requiring an amputation, according to the final regression model.

Several different studies emphasize the importance of proactive intervention, with care provided by a multidisciplinary team and focusing on caring for the high-risk population. ${ }^{6,8,17,18}$

According to the International Consensus on the Diabetic Foot, ${ }^{9}$ people should undergo, as a minimum, one examination of the feet per year (and more frequently if the risk of complications is high). ${ }^{9}$ The consensus also insists, in agreement with several different studies, that these examinations are an essential component of adequate management of this complication, involving investigation of the feet's protective sensitivity, their structure, biomechanics and circulation and the integrity of their skin, using simple and low-cost tests.

The majority of these measures fall within the scope of the responsibilities and competencies of primary care professionals, both those related to an examination of the lower limbs to identify feet at risk and the educational activities. However, although these professionals do recognize the importance of educational initiatives, citing them as an effective 
strategy for managing disease and a way of dealing with the growing demand for consultations, some have reported difficulties with relation to planning, implementing and assessing the process. ${ }^{17}$

The findings reported here with relation to examinations of and guidance given to diabetic patients with relation to their feet reveal that these practices have not yet been incorporated into the routine activities of Primary Care services and are important factors associated with amputations among these patients, even acknowledging the methodological limitations of this study.

One limitation of this study is related to a possible memory bias, since factors related to preventative care received previously were surveyed by questioning patients when hospitalized for diabetic feet. However, it is believed that this bias was minimal, in view of the relevance to their current conditions.

Among the factors that were identified in this study as being associated with amputation of lower limbs because of diabetic feet, those that stand out are related to the (preventative) Primary Care received, particularly the extensive interval since onset of the problem with the foot, the lack of information about the glycemia test results and the lack of guidance on caring for feet.

\section{REFERENCES}

1. Armstrong DG, Cohen K, Courric S, Bharara M, Marston W. Diabetic foot ulcers and vascular insufficiency: our population has changed, but our methods have not. J Diabetes Sci Tech. 2011;5(6):1591-5. http://dx.doi.org/10.1177/193229681100500636. PMid:22226282

2. Lee KM, Kim WH, LeeJH, Choi MSS. Risk factors of treatment failure in diabetic foot ulcer patients. Arch Plast Surg. 2013;40(2):123-8. http://dx.doi.org/10.5999/aps.2013.40.2.123. PMid:23532959

3. Brechow A, Slesaczeck T, Münch D, et al. Improving major amputation rates in the multicomplex diabetic foot patient: focus on the severity of peripheral arterial disease. Ther Adv Endocrinol Metab. 2013;4(3):83-94. http://dx.doi. org/10.1177/2042018813489719. PMid:23730502

4. Konstantikaki $\mathrm{V}$. The role of primary care in the prevention of diabetic foot amputations. Int J Caring Sci. 2008;1(1):26-33.

5. Prompers L, Schaper N, Apelqvist J, et al. Prediction of outcome in individuals with diabetic foot ulcers: focus on the differences between individuals with and without peripheral arterial disease. The EURODIALE Study. Diabetologia. 2008;51(5):747-55. http:// dx.doi.org/10.1007/s00125-008-0940-0. PMid:18297261

6. Caiafa JS, Castro AA, Fidelis C, Santos VP, Silva ES, Sitrângulo CJ Jr. Atenção integral ao portador de pé diabético. J Vasc
Bras. 2011;10(4, Supl 2):1-32. http://dx.doi.org/10.1590/ S1677-54492011000600001.

7. Weck M, Slesaczeck T, Paetzold $\mathrm{H}$, et al. Structured health care for subjects with diabetic foot ulcers results in a reduction of major amputation rates. Cardiovasc Diabetol. 2013;12(1):45. http:// dx.doi.org/10.1186/1475-2840-12-45. PMid:23497152

8. Alvarsson A, Sandgren B, Wendel C, Alvarsson M, Brismar K. A retrospective analysis of amputation rates in diabetic patients: can lower extremity amputations be further prevented? Cardiovasc Diabetol. 2012;11(1):18. http://dx.doi.org/10.1186/1475-2840-1118. PMid:22385577

9. International Working Group on the Diabetic Foot. International consensus on the diabetic foot and practical guidelines on the management and prevention of the diabetic foot [DVD]. Brussels: International Diabetes Federation (IDF); 2011.

10. Brasil. Ministério da Saúde. Secretaria de Políticas de Saúde. Departamento de Ações Programáticas Estratégicas. Plano de reorganização da atenção à hipertensão arterial e diabetes mellitus: manual de hipertensão arterial e diabetes mellitus. Brasília: Ministério da Saúde; 2002.

11. Assumpção EC, Pitta GB, Macedo $A C L$, et al. Comparação dos fatores de risco para amputações maiores e menores em pacientes diabéticos de um Programa de Saúde da Família. J Vasc Bras. 2009;8(2):133-8. http://dx.doi.org/10.1590/ S1677-54492009000200006.

12. Venermo $M$, Manderbacka $K$, Ikonen T, Keskimäki I, Winel $\mathrm{K}$, Sund R. Amputations and socioeconomic position among persons with diabetes mellitus, a population-based register study. BMJ Open. 2013;3(4):e002395. http://dx.doi.org/10.1136/ bmjopen-2012-002395. PMid:23572197

13. García-Álvarez Y, Lázaro-Martínez JL, García-Morales E, Cecilia-Matilla A, Aragón-Sánchez J, Carabantes-Alarcón D. Morphofunctional characteristics of the foot in patients with diabetes mellitus and diabetic neuropathy. Diabetes Metab Syndr. 2013;7(2):78-82. http://dx.doi.org/10.1016/j.dsx.2013.02.029 PMid:23680245

14. Vieira-Santos ICR, Souza WV, Carvalho EF, Medeiros MCW, Nóbrega MGL, Lima PMS. Prevalência de pé diabético e fatores associados nas unidades de saúde da família da cidade do Recife, Pernambuco, Brasil, em 2005. Cad Saude Publica. 2008;24(12):2861-70. http://dx.doi.org/10.1590/S0102311X2008001200015. PMid:19082277

15. Dos Santos Tavares DM, Dias FA, Araújo LR, Pereira GA. Perfil de clientes submetidos a amputações relacionadas ao diabetes mellitus. Rev Bras Enferm. 2009;62(6):825-30. http://dx.doi. org/10.1590/S0034-71672009000600004. PMid:20098872

16. Kafaie P, Noorbala MT, Soheilikhah S, Rashidi M. Evaluation of patients' education on foot self-care status in diabetic patients. Iran Red Crescent Med J. 2012;14(12):829-32. http://dx.doi. org/10.5812/ircmj.1138. PMid:23482390

17. Santos L, Torres HC. Práticas educativas em Diabetes Mellitus: compreendendo as competências dos profissionais da saúde. Texto Contexto Enferm. 2012;21(3):574-80. http://dx.doi. org/10.1590/S0104-07072012000300012.

18. Bortoletto MSS, Haddad MCL, Karino ME. Pé diabético, uma avaliação sistematizada. Arq Ciênc Saúde Unipar. 2009;13(1):37-43. 
Correspondence Isabel Cristina Ramos Vieira Santos Rua Teles Junior, 475, apto. 201 - Rosarinho CEP 52050-040 - Recife (PE), Brazil Tel.: +55 (81) 32426575/88886575 E-mail: tutornad@yahoo.com.br

Author information ICRVS - PhD in Sciences from Centro de Pesquisas Aggeu Magalhães (CPqAM), Fundação Oswaldo Cruz (FIOCRUZ). EFC - PhD in Social and Sanitary Sciences from Universidad Complutense de Madrid. WVS - PhD in Public Health from Fundação Oswaldo Cruz (FIOCRUZ).

ECA - MSc in Public Health from Centro de Pesquisas Aggeu Magalhães (CPqAM), Fundação Oswaldo Cruz (FIOCRUZ).

Author contributions Conception and design: ICRVS, EFC, WVS Analysis and interpretation: ICRVS, WVS, ECA

Data collection: ICRVS

Writing the article: ICRVS

Critical revision of the article: EFC Final approval of the article*: ICRVS, EFC, WVS, ECA Statistical analysis: WVS, ECA Overall responsibility: ICRVS

* All authors have read and approved of the final version of the article submitted to I Vasc Bras. 